\title{
Pengenalan teknik Pembuatan Kapsul Black Garlic di Desa Sembalun Bumbung
}

\author{
Sopiati Alawiyah ${ }^{1}$, Mia Maharani Dewi², M. Sarjan ${ }^{3 *}$ \\ ${ }^{1}$ Fakultas Ekonomi dan Bisnis, Universitas Mataram, Indonesia. \\ ${ }^{2}$ Prodi Hubungan Internasional, Universitas Mataram, Indonesia. \\ ${ }^{3}$ Pascasarjana, Universitas Mataram, Indonesia.
}

\section{Article Info}

Received: November $18^{\text {th }}, 2020$

Revised: December 21 th, 2020

Accepted: December 30th, 2020

\begin{abstract}
Abstrak: Pengabdian pada masyarakat yang melibatkan mahasiswa dalam Kuliah Kerja Nyata (KKN) tematik untuk meningkatkan nilai tambah pangan local potensial. Pada kegiatan ini focus pada pengolahan bawang putih fermentasi menjadi Black Garlic Kapsul dilaksanakan di Desa Sembalun Bumbung, Kecamatan S e m b a 1 u n, Kabupaten Lombok Timur, Provinsi Nusa Tenggara Barat. Kelompok sasaran terdiri da r i kelompok masyarakat tani, pemuda-pemudi, ibu-ibu PKK dengan memberikan informasi pengetahuan dan keterampilan pengolahan bawang putih permentasi menjadi produk olahan pangan berupa Black Garlic kapsul yang prospektif sebagai peluang usaha untuk meningkatkan ekonomi masyarakat setempat. Black garlic kapsul merupakan inovasi baru dari dari hasil permentasi bawang putih. Pembuatan Black Garlic kapsul menjadi alternatif lain untuk konsumen yang selama ini ingin hidup sehat dengan mengkonsumsi Black Garlic namun tidak bisa mencium aroma black garlic itu sendiri. Metode Kegiatan yang akan dilaksanakan meliputi penyampaian materi mengenai pengembangan Black Garlic, demonstrasi dan pelatihan pembuatan produk dilengkapi dengan pelatihan teknik pengemasan dan pemasaran, melakukan pendampingan dan pembimbingan kepada mitra, dan evaluasi kegiatan selama pelatihan. Kegiatan ini mendapat respon positif dari aparat desa dan warga masyarakat setempat, hal ini dapat ditunjukkan dengan antusiasnya peserta dalam menerima inovasi baru dan mitra aktif mengikuti kegiatan pelatihan. Hasil kegiatan ini menghasilkan peningkatan kemajuan mitra dalam pengetahuan dan wawasan dalam pengolahan black garlic, peningkatan kemampuan dan keterampilan mempraktikkan hasil olahannya dengan baik dan menarik sehingga mereka tertarik untuk membuat sendiri dan membuka usaha kecil untuk menambah pendapatan keluarga.
\end{abstract}

Kata Kunci: Black Garlic Kapsul; Produk Olahan; Sembalun Bumbung.

Abstract: Introducing an appropriate technology by University of Mataram student group of KKN (Kuliah Kerja Nyata) or Community Service program was conducted in Sembalun Bumbung village Sembalun District, East Lombok Regency, West Nusa Tenggara Province. One of the aim of this program is to improve the added values of local existing product suchof as "Black Garlic" that was modified into into Black Garlic Capsules. The program targeted partners of farmer groups, youths, and PKK (Pendidikan Keseahteraan Keluarga) group by providing information on knowledge transfer and fermented garlic skill becomes a food product ( Black Garlic Capsules) as the prospective business opportunity to increase the economy of the local community. The methods used in this program including the steps as follows, Intoducing the research on the development of black garlic, the demonstration and training on product manufacture, packaging and marketing training, assisting and mentoring to partnership and conducting evaluation during training. The result of this program showed a positive response from village officials and its local people as c indicated byan be seen from the enthusiasm of the participant during the training and actively involved in the partnership. In addition, from this program indicated that the rapid knowledge improvement of the partnership on producing Black Garlic, the skill and capability improvement in practicing the processed product by the partnership, as well as it makes them interested to produce black garlic capsules to gain additional income for their family.

Keywords: Black garlic capsules; Processing product; Sembalun.

Citation: $\quad$ Alawiyah, S., Dewi, M.M., Sarjan, M (2020). Pengenalan teknik Pembuatan Kapsul Black Garlic di Desa Sembalun Bumbung. Unram Journal of Community Service 1(1), 12-19. 


\section{Pendahuluan}

Desa Sembalun Bumbung terletak pada ketinggian $1200 \mathrm{mdpl}$ diatas permukaan Laut. memiliki Luas Wilayah 5. $597 \mathrm{Ha}$, dengan Jumlah Penduduk pada tahun 2016 sebesar 8.132 Jiwa dengan jumlah KK 2.242 yang terdidiri dari laki-laki 4.115 jiwa dan perempuan 4.017 jiwa dan pada tahun 2017jumlah penduduknya sebesar 8.426 Jiwa dengan Jumlah KK 2.316 yang terdiri dari laki-laki 4.087 jiwa dan perempuan 4.339 jiwa. Jarak Tempuh dari Ibu Kota Kecamatan Sembalun Sepanjang 6 KM dan di tempuh selama15 Menit dan Ke Ibu Kota Kabupaten Sepasnjang $33 \mathrm{KM}$ dan di tempuh selama 2 JamSerta jarak ke Ibu Kota Propinsi Sepanjang 89 Km .dan di tempuh selama 3 Jam Batas-batas wilayah Desa Sembalun Bumbung adalah Sebelah Utara Desa Sembalun Lawang Sebelah Selatan Desa Sapit dan Desa Sebelah Timur Desa Perigi dan Sebelah Barat Desa Sembalun Lawang. Desa sembalun bumbung terkenal dengan pesona alamnya yang sangat indah dan juga di anugerahi sumber daya alam yang melimpah. 90\% masyarakat sembalun bumbung menjadi petani. Hasil pertanian dan perkebunannya pun cukup beragam dan semuanya tumbuh dengan baik di tanah Sembalun. Produk unggulan desa sembalun diantaranya adalah bawang putih, strawberry, kopi, paprika, wortel, kentang, kacang merah, bawang merah, tomat, cabai besar, seledry dan salada.

Dari sekian banyak produk hasil pertanian yang ada di sembalun bumbung bawang putih adalah produk olahan yang menjadi primadona di sembalun bumbung. Tanaman bawang putih hampir bisa kita temui disetiap lahan pertanian yang ada di Sembalun. Bawang putih merupakan salah satu jenis dari komoditas horticultura yang banyak digunakan oleh masyrakat Indonesia sebagai pelengkap bumbu masak. Perkembangan pemerintaan bawang putih di Indonesia semakin meningkat seiring dengan lahu pertumbuhan penduduk, perkembnagan ekonomin dan kesadar masyarkat terhadap kebutuhan gizi. Bawang putih dapat digunakan sebagai obat anti jamur dan bakteri serta dapat menurunkan kadar kolesterol dan mencegah pembekuan darah. Selain itu bawang putih dapa digunakan untuk pengobatan penyakit hipertensi, hiperkolesterollemia, diabetes, demam atau sebagai obat pencegah arheroklerosis dan sebagai penghambat tumbuhnya tumor (Harinta, \& Basuki, 2018).

Melimpahnya tanaman bawang putih memiliki alasann bahwa proses menanam bawang putih yang relatif mudah dan memiliki nilai ekonomis yang tinggi. Menurut Peraturan Pemerintah RI nomor 28 tahun 2004 pangan adalah segala sesuatu yang berasal dari sumber hayati dan air, baik yang diolah maupun yang tidak diolah, yang diperuntukkan sebagai makanan atau minuman bagi konsumsi manusia, termasuk bahan tambahan pangan, bahan baku pangan, dan bahan lain yang digunakan dalam proses penyiapan, pengolahan dan atau pembuatan makanan atau minuman (Peraturan Pemerintah Nomor 28 Tahun 2004). Pangan adalah segala sesuatu yang berasal dari sumber hayati dan air, baik yang diolah maupun tidak diolah. Yang diperuntukkan sebagai makanan atau minuman bagi konsumsi manusia termasuk sebagai bahan tambahan pangan, bahan baku pangan, dan bahan lain yang digunakan dalam proses penyiapan, pengolahan, dan atau pembuatan makanan atau minuman (Peraturan Badan Pengawas Obat dan Makanan Tahun 2011). Dalam kamus besar bahasa Indonesia pengertian pangan olahan adalah makanan jadi yang merupakan hasil olahan yang diolah untuk diperdagangkan. Pangan olahan adalah makanan atau minuman hasil proses dengan cara atau metode tertentu dengan atau tanpa bahan tambahan, termasuk bahan pangan olahan tertentu, bahan tambahan pangan, pangan produk rekayasa genetika, dan pangan iradiasi.

Melalui kegiatan Kuliah Kerja Nyata yang dilakukan oleh tim KKN Universitas Mataram di Sembalun Bumbung setelah melakukan observasi mengenai pengembangan Black Garlic yang ada di sembalun bumbung.. Black Garlic merupakan produk fermentasi dari bawang putih yang dipanaskan pada suhu $65-80^{\circ} \mathrm{C}$ dengan kelembapan $70-80 \%$ dari suhu kamar selama satu bulan. Black garlic memiliki warna hitam, ringan karena kadar airnya berkurang dan mempunyai aroma serta rasa yang tidak terlalu menyengat seperti bawang putih. Dalam bawang putih hitam, S-allylcysteine membantu penyerapan allicin sehingga metabolisme perlindungan terhadap infeksi bakteri menjadi lebih mudah (Kosasih, 2018). Untuk produk Black Garlic sendiri terdiri dari dua macam yaitu Black Garlic biasa dan Black Garlic nunggal. Produk Black Garlic memiliki sejumlah manfaat yang sangat baik bagi kesehatan di antaranya adalah mengobati penyakit kronis, menurunkan kadar kolesterol, kanker, tekanan darah tinggi, tumor, awet muda, mempercantik kulit, membersihkan darah kotor, paruparu, mecegah stroke, serangan jantung, memperbaiki sistem pencernaan, meringankan penyakit Parkinson, mencegah diabetes, membuang logam berat dalam badan, mencegah Alzheimer, memperbaiki sel mati, melegakan sakit sendi, menstabilkan gula darah, menyehatkan dan menghangatkan badan. Selain itu, penelitian yang lain menunjukkan jika Bawang Hitam/Bawang Putih Hitam Black Garlic juga sangat 
baik dalam mencegah penuaan dini. Menurut penelitian yang dilakukan menunjukkan bahwa proses fermenteasi yang terjadi dari bawang putih tadi untuk bisa mendapatkan Bawang Hitam/Bawang Putih Hitam (Black Garlic ) sudah terbukti sangat baik membantu meningkatkan kadar polifenol dan flavonoid didalam Bawang Hitam /Bawang Putih Hitam Black Garlic. Kadar dari polifenol yang semakin meningkat hingga 23\% sedangkan untuk akdar flavonoidnya meningkat hingga 37\% didalam Bawang Hitam/Bawang Putih Hitam Black Garlic .

Polifenol dan flavonoid ini bekerja sebagai antioksidan yang bisa mencegah penyakit kanker muncul, serta penuaan dini. adanya sumber antioksidan yang akan menangkap dan mengikat radikal radikal bebas yang menyebabkan kerusakan di dalam sel-sel tubuh. dengan kadar antioksidan yang meningkat secara alami didalam Bawang Hitam/Bawang Putih Hitam Black Garlic, maka resiko penyakit kanker dan penuaan dinipun bisa diturunkan (Abadi, 2017).

Produk Black Garlic yang ada di Sembalun Bumbung sudah dapat merambah pasar internasional. Penjualan Black Garlic sudah pada tahap ekspor ke negara tetangga seperti Thailand, Malaysia dan Jepang. Problema yang ditemukan di lapangan menemukan bahwa permintaan akan Black Garlic begitu tinggi namun juga dibarengi dengan banyaknya konsumen yang tidak dapat mengkonsumsi Black Garlic karena tidak bisa mencium bau dari Black Garlic itu sendiri. Sehingga dibuatlah suatu inovasi baru pembuatan Black Garlic kapsul Dimana proses pembuatan Black Garlic kapsul ini sama dengan pembuatan Black Garlic pada umunya tetapi hanya menambah beberapa tahap finisihing sebelum dimasukan kedalam kapsul. Penambahan proses itu ialah Black Garlic yang di telah di oven kemudian akan dimasukkan kedalam mejikom Selama 30 hari sampai bawang benar-benar kering sempurna. Setelah itu baru pada tahap terakhir bawang yang telah di masukkan kedalam mejikom kemudian di blender dan dimasukkan kedalam kapsul dan siap di pasarkan.

Sasaran program Kegiatan Kuliah Kerja Nyata ini ditunjukkan pada kelompok masyarakat tani pada khsusunya dan masyarakat Sembalun Bumbung pada umumnya. Sebagai mitra yang dapat dikategorikan belum betul-betul produktif karena keterbatasan pengetahuan, keahlian, keterampilan dan pembimbingan menjadikan salah satu faktor penyebab belum adanya pengembangan penganekaragaman produk olahan pangan di Desa Sembalun Bumbung. Kegiatan ini menjadi bentuk pengenalan pengembangan teknologi dan inovasi terbaru yang belum pernah dikembangkan sebelumnya seperti Black Garlic Kapsul. Inovasi proses merupakan saran untuk meningkatkan kualitas dan juga penghematan biaya. Hal ini mencerminkan bahwa adopsi proses inovasi diakui dapat mningkatakan efisiensi produksi dan kualitas produk yang dihasilkan (Hartini, 2012).

Kegiatan pengabdian kepada masyarkat di Desa Sembalun Bumbung ini bertujuan untuk memberikan pelatihan dan pembimbingan keterampilan, keahlian dan memotivasi masyarakat Desa sembalun Bumbung dalah pengolahan produk bawang putih permentasi atau Black Garlic, bentuk kapsul sebagai penambahan tingkat perekonomian dan peningkatan mutu kualitas ekonomi serta menambah tingkat peluang usaha sehingga meningkatkan tercapainya kesejahteraan masyarakat setempat.

\section{Metode Pelaksanaan}

\section{Waktu dan Tempat}

Kegiatan ini dilakukan selama 3 Minggu mulai dari tanggal 4 Agustus sampai 24 Agsutus 2019 di Desa Sembalun Bumbung, Kecamatan Sembalun Kabupaten Lombok Timur Provinsi Nusa Tenggara Barat. Pelaksanaannya setelah melalui research dan fakta di lapangan yang memberikan alasan kegiatan inovasi black garlic dalam bentuk kapsul untuk diajarkan kepada masyarkat Sembalun Bumbung. Kegiatan sosialisasi di lakukan di Kantor Desa Sembalun Bumbung dengan mengundang Ibu-ibu PKK, Pemudapemudi Desa Sembalun Bumbung, Perangkat Desa Sembalun Bumbung.

\section{Alat dan Bahan}

Alat yang digunakan dalam proses pembuatan black garlic adalah belender, gunting, oven, megicom, tisu, sendok, saringan, wadah, masker dan sarung tangan. Bahan terdiri dari bawang putih setelah di permentasi, silica gel, kapsul dan botol kapsul.

\section{Metode}

Metode pelaksanaan program ini diawali dengan pendekatan kepada masyarakat mitra yang ada di Sembalun Bumbung bersifat formal dan nonfiormal meluli sosialisasi dan melakukan silaturahmi dengan msyarakat setempat, aparat desa, kelompok pkk, tetua adat, tokoh masyarakat di desa sembalun bumbung dengan tujuan untuk mengetahui karakterv masyarakat dan motivasi masyarakat, sehingga memudahkan dalam menentukan metode yang akan digunakan pada kegiatan ini. Adapun teknik pelaksanaan yang dilakukan dalam beberapa cara yaitu:

1) Memberikan penyuluhan kepada masyarkat mengenai inovasi black garlic dalam bentuk kapsul dan menyampaikan pengembangan black garlic kapsul sebagai peluang usaha. 
2) Demonstrasi dan pelatihan pembuatan produk olahan black garlic yang dilengkapi dengan pelatihan teknik pengemasan dan pemasaran.

3) Melakukan pendampingan dan pembimbingan kepada mitra selama pelatihan

4) Melakukan evaluasi kegiatan dengan dengan melihat antusias mitra dalam mempraktekkan produk black garlic kapsul serta ketertarikan mitra terhadap produk yang dihasilkam dan keinginan mencoba sebagai peluang usaha.

\section{Hasil dan Pembahasan}

Menurut Yusuf Waluyo Jati, desa Sembalun Bumbung sangat terkenal dengan pusat produsen bawang putih di Indonesia (Simamora, 2019). Oleh karena itu pemanfaatan bawang putih yang ada di Sembalun Bumbung tersebut adalah dengan diciptakannya produk black garlic atau bawang hitam yang telah merambah ke pasar internasional. Pemasarannya telah sampai pada kegiatan ekspor wilayah Asia yaitu, Malayasia, Jepang dan Thailand. Sebuah studi yang dilakukan pada tahun 2009 menunjukkan bahwa bawang hitam memiliki lebih banyak antioksidan dibanding dengan bawang putih biasa. Studi lainnya mengungkapkan bahwa bawang putih hitam memiliki tingkat antioksidan dua kali lebih banyak dibandingkan bawang putih yang berwarna putih (https://garlickapsul.com). Bawang putih hitam (black garlic) disebut-sebut sebagai alternatif menyehatkan bawang putih biasa. Bawang putih ini mengandung antioksidan SAC yang bisa mengurangi kerusakan sel. Bawang putih dikenal memiliki sejumlah manfaat kesehatan, tetapi rasa dan aromanya yang menusuk membuat banyak orang tidak menyukainya. Kehadiran bawang putih hitam pun dipercaya bisa menjadi alternatif bawang putih biasa karena tidak menimbulkan bau mulut saat dikonsumsi. Bawang putih hitam merupakan hasil fermentasi bawang putih. Untuk membuatnya, bawang ditaruh dalam oven yang telah dipanaskan dalam suhu tertentu dan magicom selama beberapa hari. Faktanya bawang hitam terbukti memiliki manfaat kesehatan dalam sejumlah studi pada hewan. Peneliti di Korea, misalnya, menemukan bawang putih hitam efektif membantu atasi kolesterol pada tikus. Sementara pada manusia, penelitian yang sama hanya sedikit (Rahmawati, 2016).

Untuk produk Black Garlic di Sembalun Bumbung sendiri sudah menghasilkan 4 macam produk yang sudah di pasarkan, diantaranya adalah:
1. Black Garlic Biasa, Black Garlic Biasa merupakan bawang putih yang telah diproses secara alamiah pada suhu 50drajat $C$ dalam waktu 40 hari, sehingga menghasilkan kandungan dan formulasi kimiawi baru dan perbedaan bawang putihnya terdapat pada bentuk seperti pada Black Garlic Biasa digunakan bawang putih biasa pada umumnya.

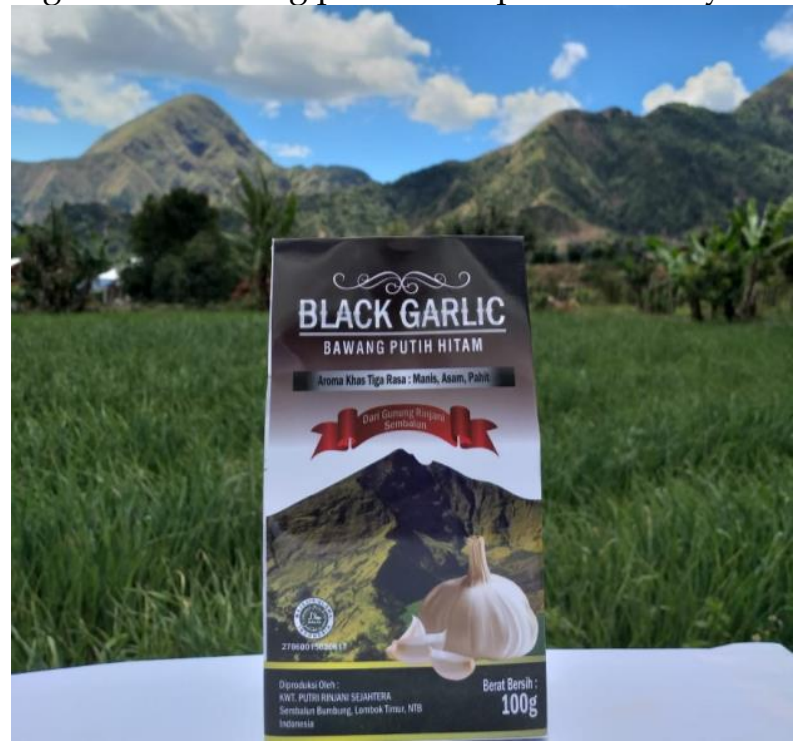

Gambar 1. Produk Black Garlic

2. Black Garlic Nunggal, merupakan bawang putih nunggal yang telah diproses secara alamiah pada suhu 50drajat $C$ dalam waktu 40 hari, sehingga menghasilkan kandungan dan formulasi kimiawi baru dan memiliki khasiat yang lebih banyak.

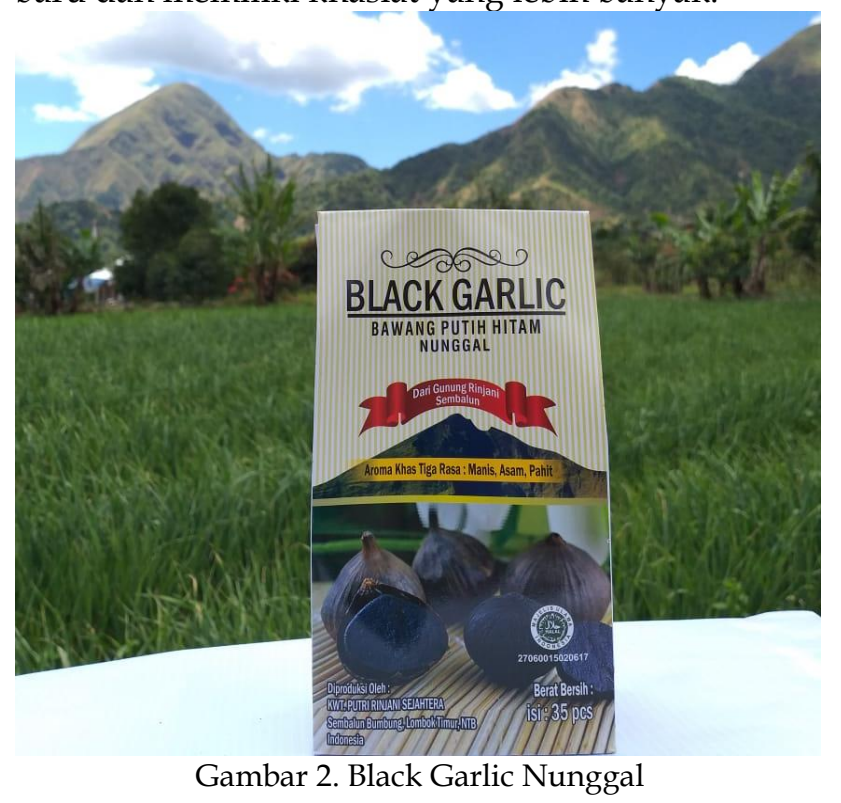

3. Black Garlic Kupas, merupakan Black Garlic yang dikemas dalam botol dalam keadaan kulit dan isinya sudah terpisahkan yang tujuannya adalah untuk mempermudah konsumen. 


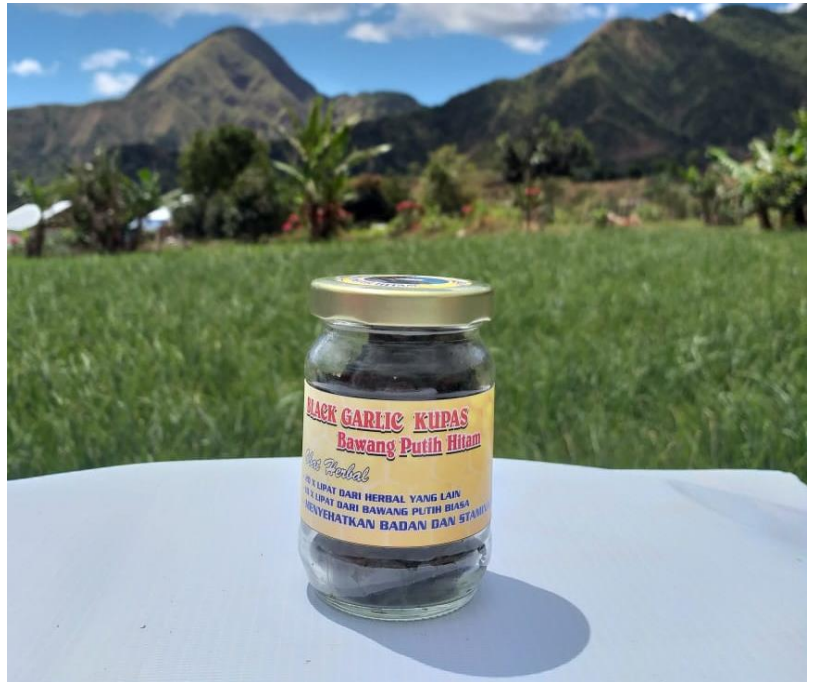

Gambar 3. Black Garlic Kupas

4. Black Garlic plus Madu, Black Garlic plus Madu merupakan perpaduan black garlic yang telah dikupas kemudian di campur dengan madu.

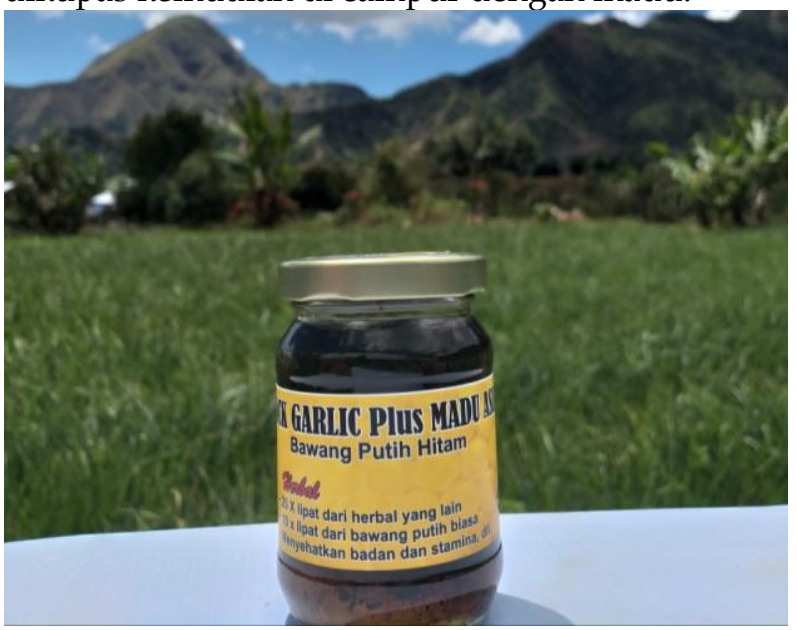

Gambar 4. Black Garlic Plus Madu

Dan salah satu program yang dapat dijalankan guna untuk memberikan inovasi baru terhadap produk Black Garlic adalah dengan membuat produk yang belum ada sebelumnya seperti Black Garlic Kapsul, Black Garlic Kapsul ini berbentuk bubuk dan dikemas dalam kapsul hingga memiliki nilai ekonomis yang lebih tinggi dan lebih praktis untuk dikonsumsi oleh konsumen terutama pada konsumen yang tidak bisa menghirup aromanya secara langsung.

Dalam menjalankan inovasi baru tentang black garlic kapsul tim KKN Sembalun Bumbung melakukan kerjasama dengan Ibu Syae'un, seorang pemilik usaha Black Garlic UD.Malsye. Proses pembuatan black garlic pun berlangsung dilakukan di rumah Ibu Syae'un. kapsul:

Tahapan-tahapan proses pembuatan black garlic

1. Proses pertama yang di lakukan adalah memasukkan bawang putih yang $100 \%$ kering ke dalam oven dan di diamkan selama 10 hari dengan suhu paling kecil yaitu 50derajat $C$.

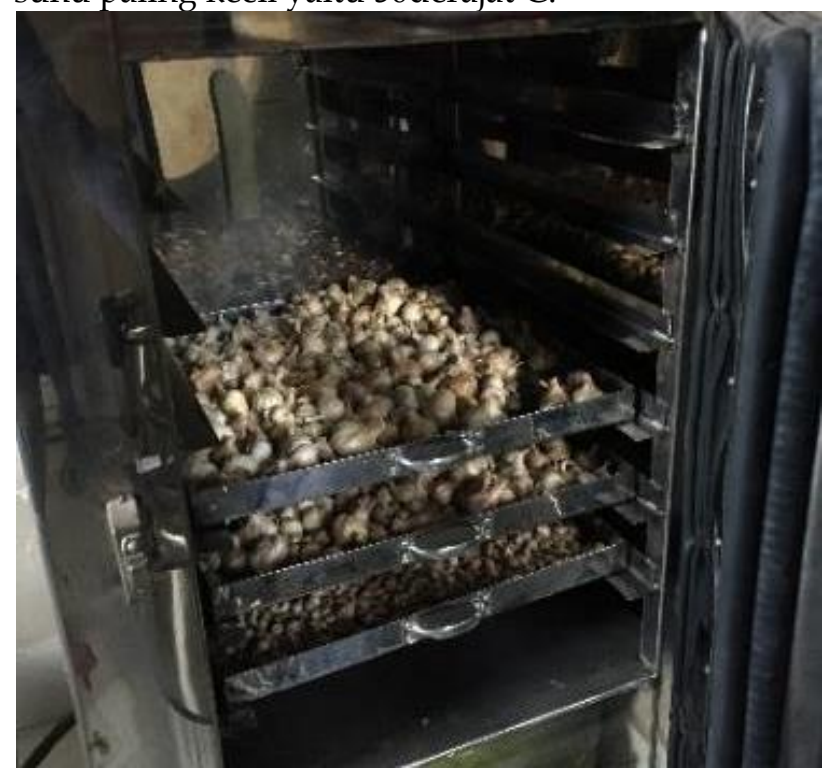

Gambar 5. Proses Memasukkan Bawang Putih ke Oven

2. Proses kedua, setelah melalui tahap pengovenan selama 10 hari bawang putih tersebut akan sedikit berubah warna menjadi kecoklatan, kemudian dimasukkan ke dalam magicom selama 30 hari dan setelah itu akan berubah warna menjadi hitam atau yang disebut black garlic, kemudian setelah itu di panen dan di kupas. Setelah di kupas di masukkan lagi ke dalam magicom selama 10 hari agar lebih kering.

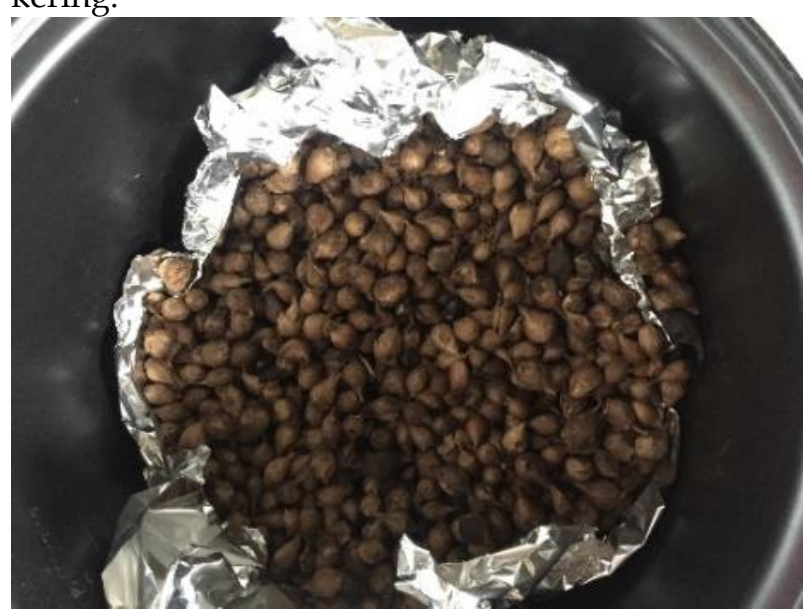

Gambar 6. Perubahan Warna Bawang Setelah di Oven

3. Proses ketiga yakni memasukkan black garlic tersebut ke dalam blender selama 2 menit, kemudian di blender sampai menjadi bubuk . 


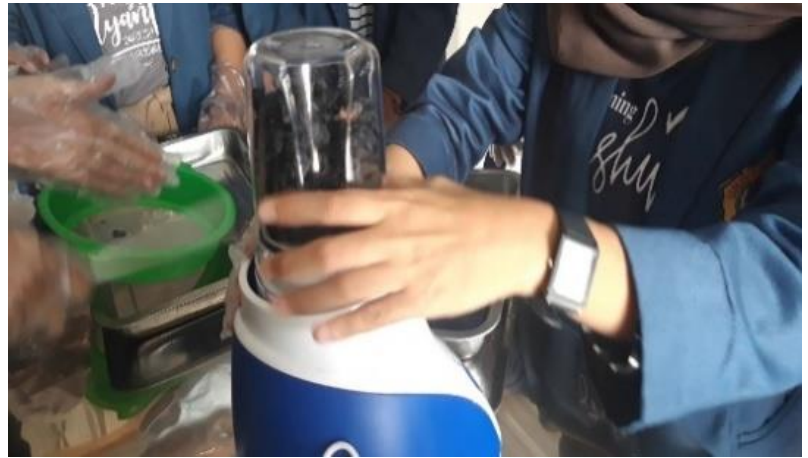

Gambar 7. Proses memasukkan Black Garlic ke dalam Blender

4. Proses ke-empat yakni menyaring bubuk black garlic yang telah di blender, memisahkan antara bubuk halus dengan kasar dan yang di ambil hanya bubuk halusnya saja.

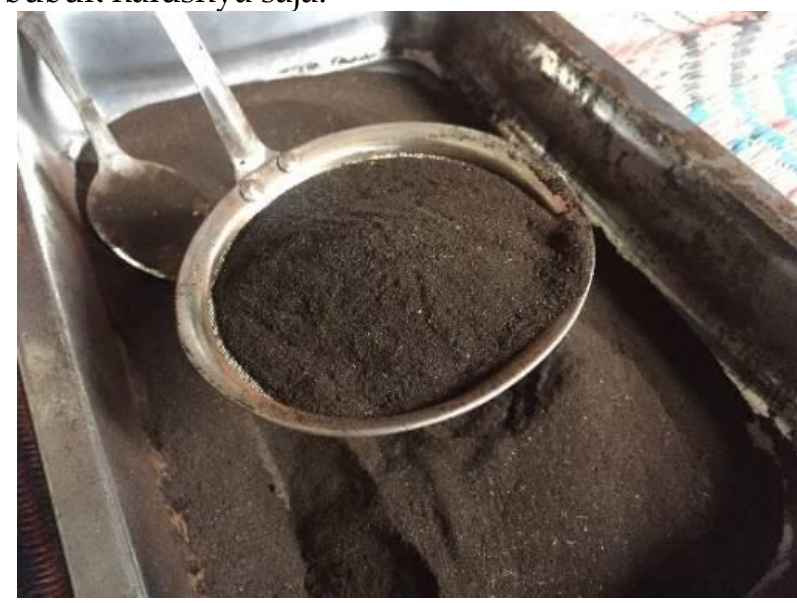

Gambar 8. Proses Penyaringan Bubuk Black Gerlic

5. Proses kelima, memasukkan bubuk black garlic yang halus ke dalam kapsul dengan cara menggunakan sendok teh kemudian dimasukkan ke dalam kapsul selanjutnya ditutup.

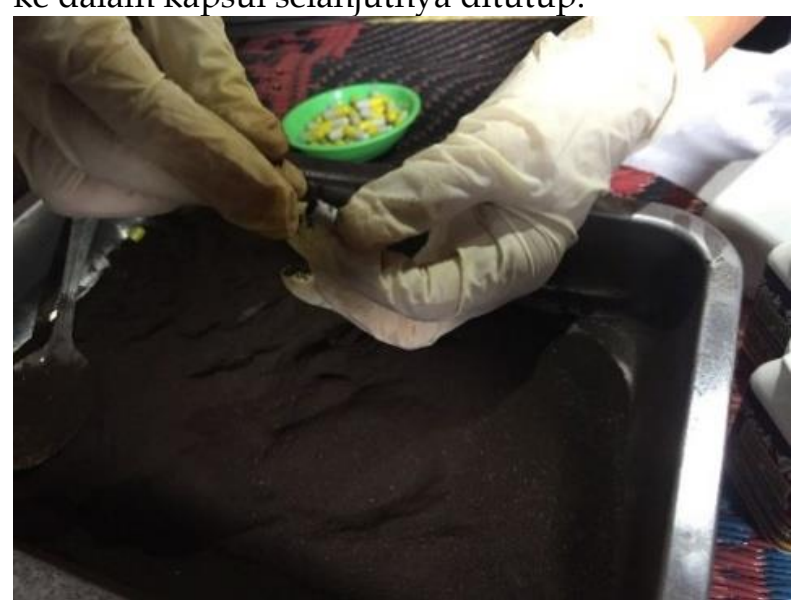

Gambar 9. Proses memasukkan Bubuk Black Gerlic ke Dalam Kapsul
6. Proses keenam setelah memasukkan bubuk black garlic ke dalam kapsul, kapsul tersebut di bersihkan menggunakn tissue yang bersih agar kapsul tetap higenis.

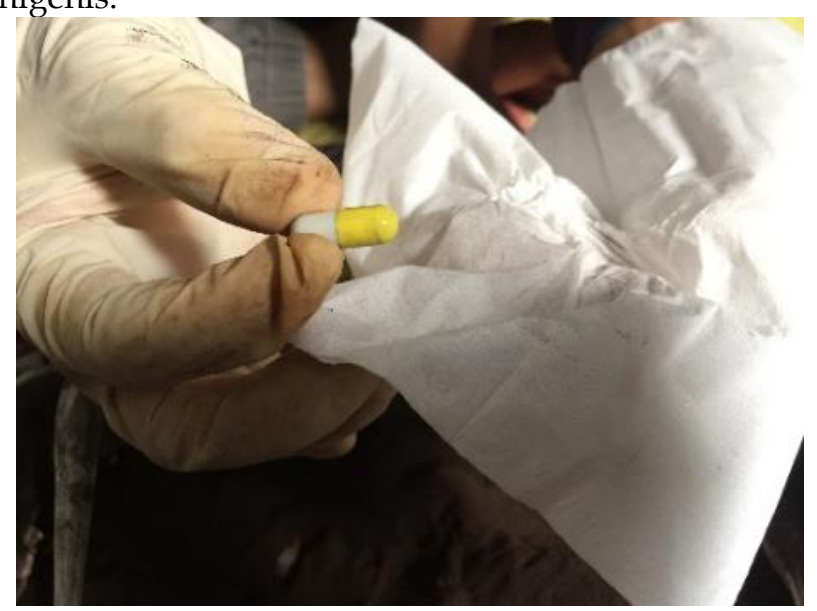

Gambar 10. Proses Membersihkan Kapsul dengan Tissue

7. Proses ketujuh yakni memasukkan silica gel terlebih dahulu ke dalam botol seagai bahan pengawet.

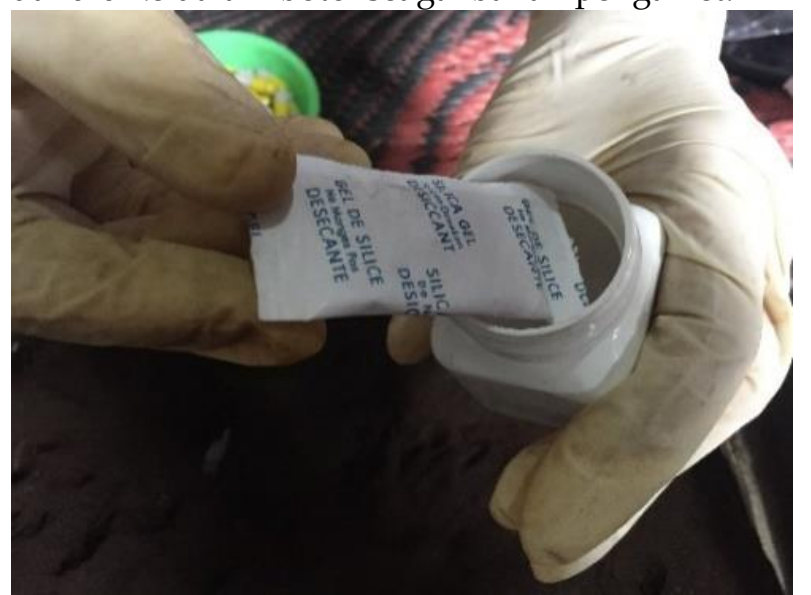

Gambar 11. Proses memasukkan silica gel ke dalam botol

8. Proses ke delapan yakni memasukkan kapsul yang telah di isi ke dalam botol kemudian botol di tutup jika sudah terisi sebanyak 50 kapsul.

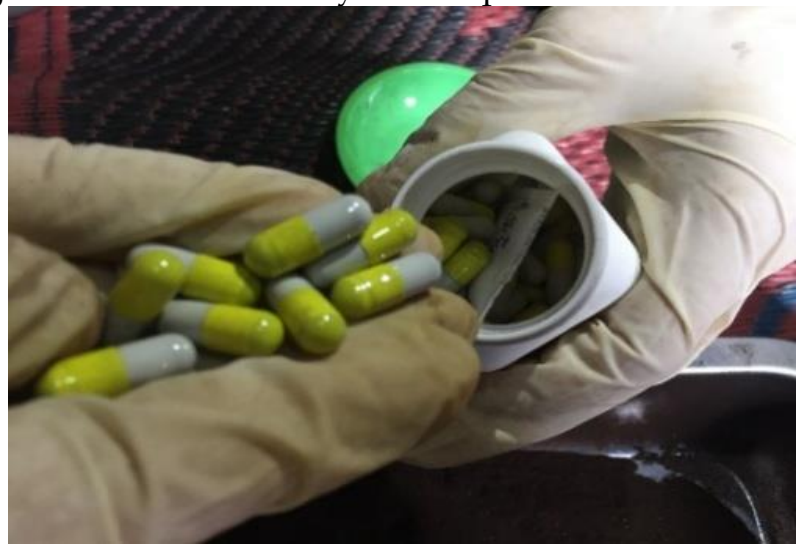

Gambar 11. Proses memasukkan kapsul ke dalam botol 
9. Kemudian setelah melalui proses-proses di atas, black garlic kapsul siap untuk di konsumsi dan dipasarkan.

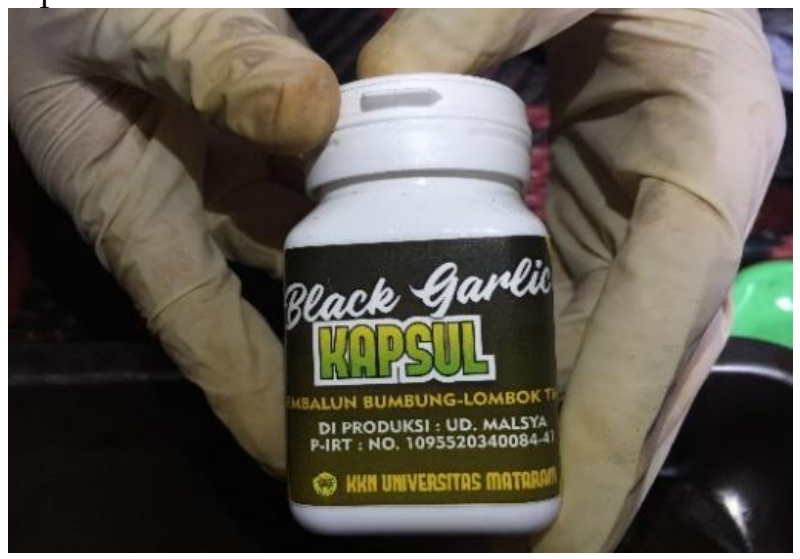

Gambar 12. Kemasan Black Gerlic yang siap Dipasarkan

\section{Analisis Harga}

Dalam menganalisis harga pada produk Black Garlic Kapsul, Tim KKN Sembalun Bumbung Universitas Mataram menggunakan rumus Break Even Point (BEP). Break Even Point atau nama lain dari analisis titik impas diartikan sebagai suatu keadaan atau titik di mana perusahaan dalam kegiatan operasinya tidak memperoleh keuntungan dan tidak mengalami kerugian juga. Penghitungan Break Even Point atau titik impas dalam sebuah usaha sangatlah penting untuk menentukan target penjualan yang harus dipenuhi dalam rangka memperoleh keuntungan usaha.

Dalam menghitung berapa besar Break Event Point (BEP) atau titik impas tentu saja memerlukan komponen-komponen. Berikut ini komponen dalam perhitungan Break Event Point (BEP): 1) Biaya Tetap (Fixed Cost), baik ketika perusahaan sedang berproduksi maupun tidak berproduksi; 2) Biaya Variable (Variabel Cost), Komponen ini bersifat dinamis dan bergantung pada tingkat volume produksinya. Jika produksi meningkat, maka biaya variabel juga akan meningkat; 3) Harga Jual (Selling Price), harga jual per unit barang atau jasa yang telah diproduksi.

Dalam produksi Black Garlic memiliki biayabiaya modal dijelaskan seperti berikut:

Komponen Biaya Harga Biaya Tetap (Fixed Cost)

Penyusutan Oven

Penyusutan Magicom

Rp. 200.000

Penyusutan Blender

Penyusutan Baskom

Penyusutan Saringan

Penyusutan Gas

Listrik

Gaji Karyawan
Rp. 70.000

Rp. 10.000

Rp. 9.000

Rp. 1.000

Rp. 7.000

Rp.1.000.000

Rp. 1.000 .000

Total $=$ Rp. 2.297 .000
Biaya Variabel (Variable Cost)

Bawang Putih Permentasi Rp. 10.000

Kapsul 50 biji

Botol

Sticker

Rp. 5.000

Rp. 3.400

Silica Gel

Biaya Lain-lain

Rp. 1.500

Rp. 100

Rp. 7.000

Total $=$ Rp. 27.000

Harga Jual (Selling Price) Rp. 50.000

Setelah mengetahui komponen-komponen dalam perhitungan Break Event Point maka di lanjutkan dengan menghitung BEP Unit, BEP Rupiah:

$>$ Menghitung BEP Unit

Rumus :

$\mathrm{BEP}$ Unit = Biaya Tetap $($ harga $/$ unit - biaya variable/unit)

BEP Unit $=$ Rp.2.297.000 (50.000-27.000) $=$ Rp. 2.297.000/Rp. $23.000=99$ unit

$>$ Menghitung BEP Rupiah

Rumus :

BEP Rupiah = Biaya Tetap (kontribusi margin/unit harga/unit)

BEP Rupiah = Rp.2.297.000 (23.000/50.000) $=$ Rp.

2.297.000/0,46 = Rp.4.993.000

Jadi, BEP Rupiah dari produk Black Garlic adalah Rp. 4.993.000.

Dengan adanya perhitungan BEP di atas, maka kesimpulannya adalah bahwa untuk memperoleh titik impas dengan harga penjualan sebesar Rp.50.000, maka perusahaan harus dapat menjual sebanyak 99 unit.

Dengan mengetahui kapan perusahaan melewati tingkat BEP, maka sebagai pemilik usaha juga dapat menghitung berapa minimal penjualan untuk mendapatkan keuntungan yang di targetkan, yaitu dengan cara menambahkan laba yang ditargetkan tersebut dengan biaya tetap yang di miliki. Misalnya target keuntungan yang ingin diperoleh dalam satu bulan adalah Rp. 10.000.000, maka minimal penjualan yang harus di capai adalah sebagai berikut:

$>\mathrm{BEP}-\mathrm{Laba}=($ biaya tetap + target laba $)($ harga $/$ unitbiaya variable/unit)

$$
\begin{aligned}
& \mathrm{BEP}-\mathrm{Laba}=(2.297 .000+10.000 .000)(50.000- \\
& 27.000) \\
& \mathrm{BEP}-\mathrm{Laba}=12.297 .000 / 23.000 \\
& \mathrm{BEP}-\mathrm{Laba}=535 \text { unit } \\
& \text { Maka dari perhitungan di atas, jika ingin }
\end{aligned}
$$
memperoleh keuntungan sebesar Rp.10.000.000 dalam satu bulan maka pemilik usaha harus memproduksi Black Garlic Kapsul sebanyak 535 unit

\section{Kesimpulan}

Berdasarkan hasil kegiatan program kerja kuliah nyata yang telah dilakukan disimpulkan bahwa: 1) Mitra sangat antusias dalam menerima inovasi baru 
terlihat dari peningkatan kemajuan mitra dalam pemahaman materi pengolahan black garlic; 2) Seluruh peserta pelatihan sudah trampil mempraktekkan pembuatan produk black garlic menjadi black garlic kapsul dan menghasilkan produk sesuai spesifikasi dan pandan menarik; 3) Mitra tertarik dan termotivasi mengembangkan produk olahan black garlic sebagai peluang usaha untuk meningkatkan perekonomian keluarga; dan 4) Mahasiswa KKN akan melanjutkan program lack garlic usaha seagai peluang usaha dengan mitra.

\section{Daftar Pustaka}

Peraturan Badan Pengawas Obat dan Makanan (2011) Tentang Pengawasan Kemasan Pangan.

Peraturan Pemerintah Nomor 28 Tahun 2004 Tentang Keamanan Gizi, dan Mutu Pangan

Kosasih, I.K. (2018). Pengaruh Suhu Dan lama Permentasi Pada Pembuatan Black Garlic Terhadap Aktivitas Anti Bakteri Eschericia Coli. Universitas Pasundan Bandung, Bandung. Hal 2.

Hartini, S. (2012). Peran Inovasi Pengembangan Kualitas Produk dan Kinerja Bisnis. Jurnal Menejemn dan Kewirausahaan, 14(1). 83-88

Harinta, Y.W., \& Basuki, J.S. (2018). Potensi Pengembangan Bawang Putih Sebagai Komoditas Unggulan Di Kabupaten Karanganyar. Jurnal Ilmu-Ilmu Pertanian, 2(2).

Rahmawati, A.A.D. (2016). Benarkah Black Garlic Lebih Sehat Dibanding Bawang Putih Biasa, https:// food.detik.com/info-sehat/d3238755/benarkah-black-garlic-lebih-sehatdibanding-bawang-putih-biasa, Pada tanggal 27 agustus 2019.

Abadi, F. (2017). Black Garlic Sembalun. http://ekonomi.kampungmedia.com/2017/10/05/black-garlic-sembalun20358, Diakes pada 21 Agustus 2019.

Garlic Kapsul Perpaduan Allium Sativum dan Bulbus Ekstrak 500mg, https://garlickapsul.com/ Pada tanggal 27 agustus 2019

Simamora, N.S. (2018). Sepenggal Cerita dari Desa Sembalun Bumbung, https://sumatra.bisnis.com/read/20180827/250 1831665/raster-sepenggal-cerita-dari-desasembalun-bumbung Pada tanggal 26 agustus 2019 